\title{
PENCEGAHAN KONSTIPASI PADA ANAK MELALUI PENYULUHAN IMPLEMENTASI EVIDENCE BASED PRACTICE TENTANG MAKANAN BERSERAT DAN AIR PUTIH
}

\author{
Lela Aini ${ }^{1 *}$, Lenny Astuti ${ }^{2}$, Dessy Suswitha ${ }^{3}$, Dea Mega Arini ${ }^{4}$, \\ Shinta Maharani ${ }^{5}$, Dewi Rury Arindari ${ }^{6}$, Sri Hartati ${ }^{7}$ \\ ${ }^{1-7}$ Sekolah Tinggi Ilmu Kesehatan Siti Khadijah Palembang \\ Email Korespondensi: lela.aini15@gmail.com
}

\begin{abstract}
ABSTRAK
Konstipasi merupakan kondisi di mana feses mengeras sehingga susah dikeluarkan melalui anus,dan menimbulkan rasa terganggu atau tidaknya pada rektum. Konstipasi dapat terjadi akibat kurangnya makan berserat, kurang minum putih dan pengaruh obat yang dikonsumsi. Salah satu hal yang bisa dilakukan untuk meningkatkan kesadaran masyarakat adalah dengan memberikan penyuluhan tentang Pencegahan konstipasi pada anak melalui penyuluhan impementasi evidence based practice tentang makanan berserat dan air putih. Tujuan Pengabdian adalah untuk Meningkatkan pemahaman anak mengenai pencegahan konstipasi melalui penyuluhan implementasi evidence based practice tentang makanan berserat dan air putih di Panti Asuhan Darussalam Palembang. Metode yang digunakan dalam kegiatan pengabdian masyarakat adalah berbentuk pendidikan kesehatan dengan metode ceramah dan demontrasi. Kesimpulan adanya peningkatan pengetahuan anak (100\%) di Panti Asuhan Darussalam Palembang tentang makanan berserat dan konsumsi air putih untuk mencegah kejadian konstipasi.
\end{abstract}

Kata Kunci: Konstipasi, Makanan berserat, dan Air Putih

\begin{abstract}
Constipation is a condition in which the stool hardens so that it is difficult to expel it through the anus, and causes discomfort or discomfort in the rectum. Constipation can occur due to lack of fiber eating, drinking less mineral water and the influence of drugs consumed. One of the things that can be done to increase public awareness is to provide counseling on the prevention of constipation in children through counseling on the implementation of evidence based practice about fibrous food and water. The purpose of this service was to increase children's understanding of preventing constipation through counseling on the implementation of evidence based practice about fibrous food and mineral water at the Darussalam Orphanage in Palembang. The method used in community service activities through health education with lecture and demonstration methods. The conclusion is that there was an increasing of knowledge of children (100\%)at the Darussalam Orphanage in Palembang about fibrous food and water consumption to prevent constipation.
\end{abstract}

Keywords: Constipation, Fibrous Food, And Mineral Water. 


\section{PENDAHULUAN}

Konstipasi merupakan kondisi di mana feses mengeras sehingga susah dikeluarkan melalui anus, dan menimbulkan rasa terganggu atau tidak nyaman pada rektum (Saputri, 2018). Konstipasi dapat terjadi pada semua lapisan usia, yang pada umumnya ditandai dengan frekuensi buang air besar yang rendah (kurang dari 3 kali dalam satu minggu (Salsabila, 2020).

Dampak yang terjadi akibat Konstipasi dapat mengakibatkan kanker usus besar (colon cancer) yang dapat berujung pada kematian (Lee et al., 2016). Prevalensi konstipasi di Indonesia adalah sebesar 3,8\% untuk usia 60-69 tahun dan 6,3\% pada 70 tahun (Permenkes RI, 2013). Konstipasi disebabkan karena proses yang mereka alami dan di dukung oleh beberapa faktor seperti kurang gerak, asupan cairan dan serat yang kurang (Isniawati \& Nirmalasari, 2019). Jika konstipasi dibiarkan terus-menerus tanpa penangganan yang tepat akan berdampak buruk pada kesehatan salah satunya kanker kolon (Lefiana, 2020).

Salah satu upaya yang dapat dilakukan untuk mencegah terjadinya konstipasi yaitu dengan mengkonsumsi makanan berserat sesuai dengan angka kecukupan gizi untuk dewasa usia 19-29 tahun adalah $38 \mathrm{~g} /$ hari untuk laki-laki dan $32 \mathrm{~g} /$ hari untuk perempuan. Sedangkan untuk konsumsi air putih yang dianjurkan untuk membantu metabolism tubuh sebanyak 1,5-2 liter perhari (Ambarita et al., 2014)

Hasil studi yang pernah dilakukan oleh (Lidwina, 2019) tentang hubungan asupan serat makanan dan cairan dengan kejadian konstipasi fungsional mengatakan bahwa rata-rata responden pernah mengalami konstipasi sebanyak 73,01\% di akibatkan kurangnya suplai cairan dan makanan berserat saat mengkonsumsi makanan. Sejalan dengan hasil studi yang dilakukan oleh Hal ini sesuai dengan hasil studi yang dilakukan oleh (Yuliastuti et al., 2020) tentang hubungan antara asupan serat dan asupan cairan dengan kejadian konstipasi didaptkan Pada kejadian konstipasi, responden yang mengalami konstipasi sebanyak 17 respoden $(56,7 \%)$ sedangkan yang tidak mengalami konstipasi sebanyak 13 responden $(43,3 \%)$, sedangkan untuk asupan cairan rata-rata responden mengkonsumsi air putih sebanyak 529,7ml-2.640 ml.

Penyuluhan kesehatan sangat diperlukan sebagai upaya meningkatkan pengetahuan dan kesadaran, di samping pengetahuan sikap dan perbuatan. Oleh karena itu, tentu diperlukan upaya penyediaan dan penyampaian informasi, yang merupakan bidang garapan penyuluhan kesehatan. Makna asli penyuluhan adalah pemberian penerangan dan informasi (Rahmad \& Almunadia, 2017). Berdasarkan analisis kajian situasi maka perlunya dilakukan kegaiatan pengabdian kepada masyarakat di Panti Asuhan Darussalam Palembang tentang makanan berserat dan air putih untuk mencegah terjadinya konstipasi.

\section{MASALAH}

Tingginya kejadian konstipasi dikalangan anak khususnya di Panti Asuhan Darussalam Palembang membuat perlunya memberikan edukasi tentang pencegahan konstipasi. Salah satu upaya pencegahan yang dapat dilakukan adalah dengan memberikan pendidikan kesehatan untuk meningkatkan pengetahuan dan kesadaran anak tentang makanan berserat dan air putih untuk mencegah kejadian konstipasi. 


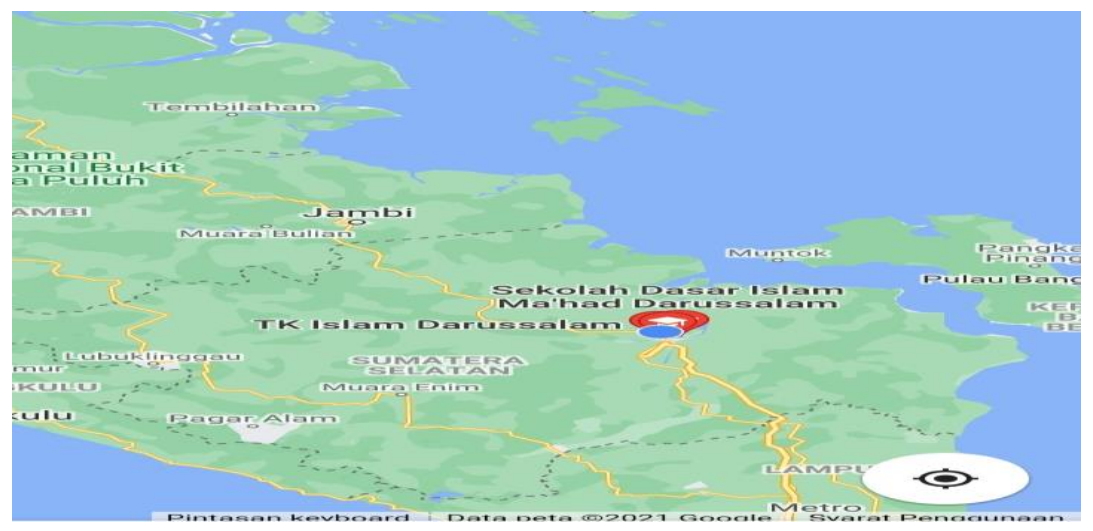

Gambar. 2.1. Lokasi Kegiatan Pengabdian kepada Masyarakat

\section{METODE}

Sasaran Kegiatan adalah semua Anak Panti di panti Asuhan Darussalam Palembang yang berjumlah 20 orang. Metode kegiatan ini berbentuk penyuluhan kesehatan dengan metode ceramah dan demontrasi makanan yang mengandung serat serta jumlah air putih yang dikonsumsi. Tahapan Kegiatan Pengabdian masyarakat yaitu sebagai berikut :

a. Tahap Perencanaan

Tahapan awal dengan penyusunan rencana yang dilakukan dengan cara wawancara dengan petugas panti di dapatkan sebagian anak di Panti Asuhan Darussalam pernah mengalami konstipasi di tandai dengan anus terasa penuh dan sakit saat BAB. Setelah didapatkan data tersebut dilakukan kegiatan Tahap Persiapan.

b. Tahap Persiapan

Dilakukan penyiapan organisasi pelaksanaan dan penyiapan aula tempat yang akan dilakukan pengabdian. Pada tahap persiapan pelaksana, tim mempersiapkan tenaga pelaksana dan pendukung yang dapat dilakukan oleh petugas panti itu sendiri. Selanjutnya, pada tahap persiapan aula, diawali dengan melakukan studi kelayakan terhadap panti asuhan yang akan dijadikan sasaran dilakukan secara formal ataupun informal. Serta target anak panti yang ikut berpartisipasi.

c. Tahap Pelaksanaan

Merupakan salah satu tahap paling penting dalam proses pengabdian kepada masyarakat. Peran petugas panti maupun anak panti sebagai sasaran program diharapkan dapat menjaga keberlangsungnya kegiatan yang telah dikembangkan. Pada tahap ini disampaikan dalam bentuk Pendidikan Kesehatan tentang implementasi makanan berserat dan konsumsi air putih.

d. Tahap Evaluasi

Tahap Evaluasi sebagai proses pengawasan dari pelaksana terhadap program pengabdian kepada masyarakat yang sedang berjalan dilakukan dengan melibatkan anak panti. Evaluasi dilaksanakan dengan mengobservasi dan menilai respon Kemampuan anak dilihat pada saat di berikan evaluasi pertanyaan tentang makanan berserat dan air putih untuk mencegah terjadinya konstipasi. 


\section{HASIL DAN PEMBAHASAN}

Berdasarkan dari hasil pengabdian kepada masyarakat yang di berikan melalui Pendidikan Kesehatan secara langsung didapatkan Sebagian anak sudah mengetahui tentang makanan berserat dan air putih dalam mencegah konstipasi. Hal ini sesuai dengan hasil studi yang dilakukan oleh Dwinoviya, Kimiko (2018) tentang hubungan antara asupan serat dan asupan cairan dengan kejadian konstipasi didaptkan hasil rata-rata usia anak yang sering mengalami konstipasi berusia 12 tahun $(38,7 \%)$ sebanyak 42 orang(93,3\%), dan rata-rata pemenuhan asupan serat responden per hari sebanyak 2,8 g-19,4 g, sedangkan untuk asupan cairan rata-rata responden mengkonsumsi air putih sebanyak 529,7 ml - $2.640 \mathrm{ml}$. Kegiatan ini dilaksanakan satu hari yaitu pada Jum'at, 10 September 2021 dari pukul 09.00-11.00WIB. Peserta kegiatan yaitu anak panti di Panti Asuhan Darussalam. Media yang dipakai berupa leaflet, spanduk dan power point, pada akhir kegiatan Pendidikan Kesehatan di lakukan evaluasi kegiatan dengan memberikan beberapa pertanyaan kepada anak panti, didapatkan sebagian anak mengerti dan memahami cara pencegahan konstipasi.

Program pengabdian masyarakat di Di Panti Asuhan Darussalam dapat diselenggarakan dengan baik dan berjalan dengan lancar sesuai dengan rencana kegiatan yang telah disusun dengan adanya Kerjasama dengan mahasiswa, petugas panti dan anak panti. Beberapa anakbelum memahami akibat dampak yang di timbulkan dari konstipasi. Kegiatan ini mendapat sambutan sangat baik terbukti dengan keikutsertaan petugas panti dan anak panti dalam kegiatan Pendidikan Kesehatan. Selain itu dilakukanProgram ini mampu memberikan pengetahuan dasar tentang Peningkatan Kesadaran Masyarakat dalam melakukan pencegahan konstipasi pada anak melalui penyuluhan impementasi evidence based practice tentang makanan berserat dan air putih. Program ini dijalankan dengan maksud memberikan proteksi tambahan kepada anak panti agar terhindar dari konstipasi.

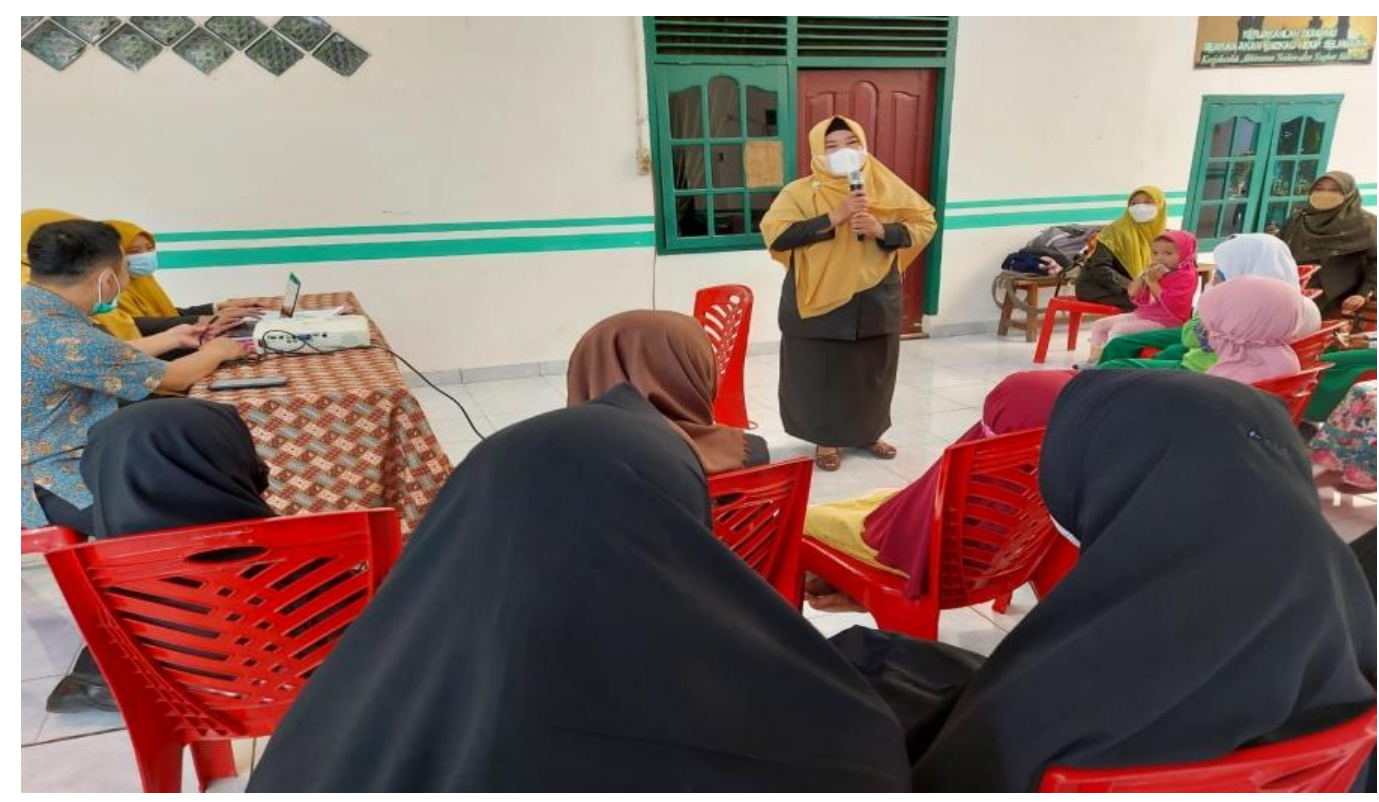

Gambar 4.1. Tahap Pelaksanaan pemberian Pendidikan Kesehatan 


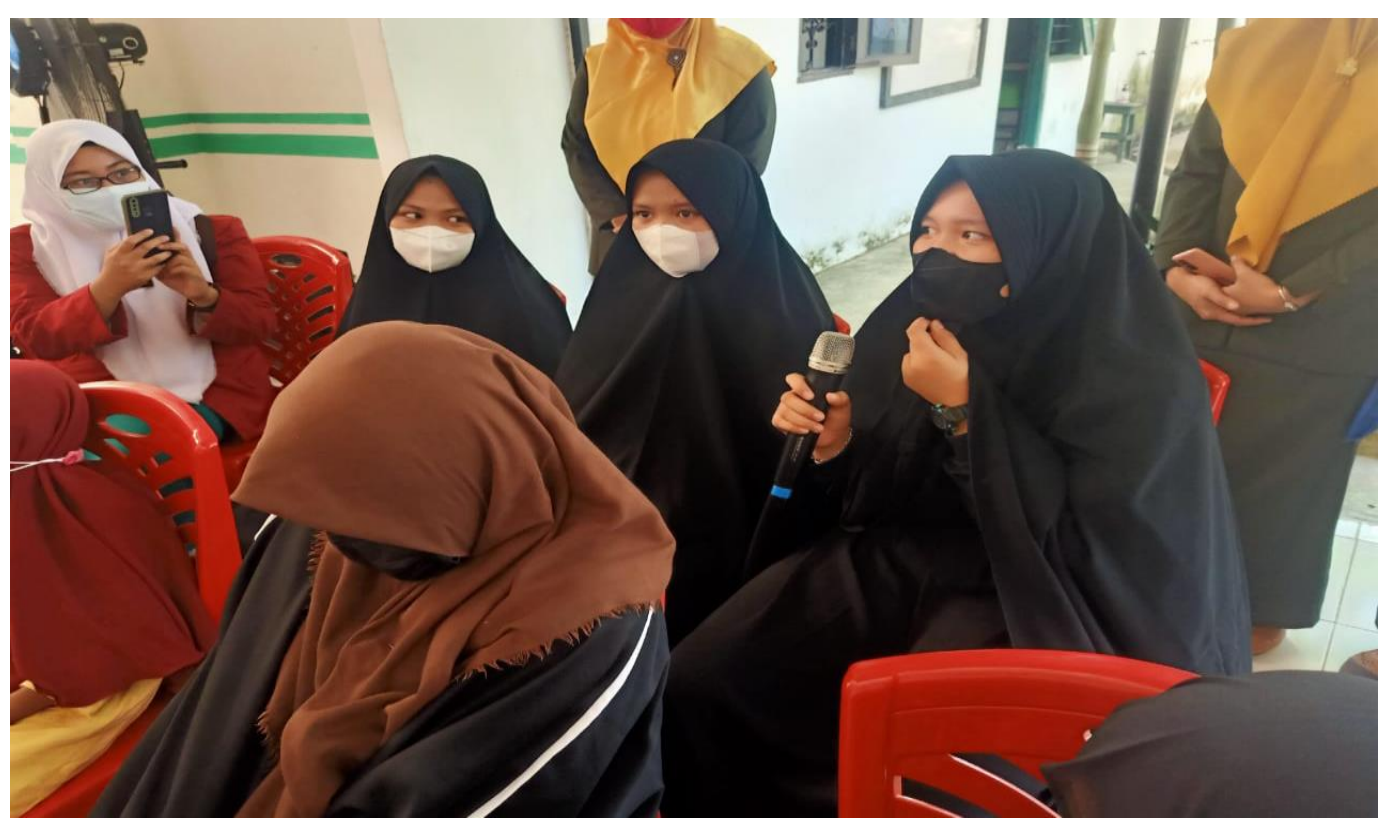

Gambar 4.2 Tahap Evaluasi memberikan pertanyaan kepada anak

\section{KESIMPULAN}

Berdasarkan hasil kegiatan pengabdian kepada masyarakat yang telah dilakukan dapat diselenggarakan dengan baik dan berjalan dengan lancar sesuai dengan rencana kegiatan yang telah disusun, maka dapat di simpulkan kegiatan ini berhasil dengan mendapatkan sambutan sangat baik terbukti dengan keikutsertaan masyarakat dalam kegiatan Pendidikan kesehatan dan meningkatnya pengetahuan anak tentang pencegahan konstipasi melalui penyuluhan implementasi evidence based practice makanan berserat dan air putih di Panti Asuhan Darussalam Palembang

\section{DAFTAR PUSTAKA}

Ambarita, E. M., Madanijah, S., \& Nurdin, N. M. (2014). Hubungan Asupan Serat Makanan Dan Air Dengan Pola Defekasi Anak Sekolah Dasar Di Kota Bogor. Jurnal Gizi Dan Pangan, 9(1), 7-14. https://doi.org/10.25182/jgp.2014.9.1.

Isniawati, F., \& Nirmalasari, N. (2019). Gambaran Karakteristik Kejadian Konstipasi Berdasarkan Nanda 2015-2017 Pada Remaja di SMA N 1 Sleman Yogyakarta. 1-2.

Lee, A., Lambert, K., Byrne, P., \& Lonergan, M. (2016). Prevalence of Constipation in Patients With Advanced Kidney Disease. Journal of Renal Care, 42(3), 144-149. https://doi.org/10.1111/jorc.12157

Lefiana, F. (2020). Hubungan Asupan Serat, Asupan Cairan, Dan Aktivitas Fisik Dengan Kejadian Konstipasi Pada Lansia (Study Literature). 44.

Lidwina, G. (2019). Hubungan asupan serat dengan kejadian konstipasi pada remaja usia 15-19 tahun di sma makarios jakarta.

Permenkes RI. (2013). Angka Kecukupan Gizi yang Dianjurkan Bagi Bangsa Indonesia.

Rahmad, A. H. Al, \& Almunadia. (2017). Pemanfaatan Media Flipchart dalam 
Meningkatkan Pengetahuan Ibu Tentang Konsumsi Sayur dan Buah. 17(3), 140-146.

Salsabila, Q. (2020). Efikasi Daun Jati Cina dalam Mengatasi Konstipasi. Jurnal Penelitian Perawat Profesional, 3(1), 41-50. https: / / doi.org/10.37287/jppp.v3i1.283

Saputri, M. A. D. (2018). Hubungan Konsumsi Air Putih dengan kejadian Konstipasi Pada Lansia di Dusun Sidorejo Desa Karas Kecamatan Karas Kabupaten Magetan. 2018.

Yuliastuti, W., Nurkhamim, K., \& Lasman. (2020). Hubungan Frekuensi Asupan Serat Makanan dan Cairan dengan Kejadian Konstipasi pada Santri Remaja di Ponpes Luhur Sulaiman Desa Serut Kecamatan Boyolangu. Media Komunikasi Ilmu Kesehatan, 12(02), 70-76.

Zainaro, M. A., Kusumaningsih, D., \& Karyanto, K. (2019). Hubungan Pelayanan Dan Fasilitas Kesehatan Dengan Kepuasan Pasien Pada Pelayanan Manajemen Terpadu Balita Sakit (Mtbs) Di Puskesmas Karya Tani Kabupaten Lampung Timur. Malahayati Nursing Journal, 1(1). 